\title{
REGULASI DIRI MAHASISWA BERPRESTASI
}

\author{
Aftina Nurul Husna, Frieda N. R. Hidayati, Jati Ariati*
}

\author{
Fakultas Psikologi Universitas Diponegoro \\ Jl. Prof. Sudharto SH, Tembalang, Semarang 50275 \\ *ariati.jati@undip.ac.id
}

\begin{abstract}
Self-regulation is considered as one of the success key for students. Self-regulation process involves one's activities to produce thoughts, feelings, and actions, to plan and continuously to adapt in order to achieve the targeted goals. This study aims to describe the experiences of best students in self-regulating themselves, particularly in improving their achievement as a student as endorsed by the university. Two students who won the Best Students Competition held by a university had participated in this study. A qualitative phenomenological approach was used in this study. Data was collected using interview and subsequently were analyzed using the transcendental phenomenological method. The study focused on finding meaning and understanding the selfregulatory process of students in pursuing their academic achievement. The findings showed that self-regulation was defined as having an integrated thoughts, feelings, and actions, continuously, and targeted in pursuing the achievement. Self-regulation was a process in guiding self towards a holistic person, academically (to be a best student), socially (to be a good child as well as a good sister), and existentially (to be a useful person).
\end{abstract}

Keywords: self-regulation, best student

\begin{abstract}
Abstrak
Regulasi diri dipandang sebagai salah satu kunci keberhasilan mahasiswa. Proses regulasi diri melibatkan keaktifan seseorang dalam menghasilkan pikiran, perasaan dan tindakan, merencanakan serta terus-menerus mengadaptasikannya guna mencapai tujuan-tujuan. Penelitian ini bertujuan untuk memahami pengalaman regulasi diri dalam konteksnya, menyangkut motif, proses dan hal-hal apa saja yang mendukungnya, terutama untuk secara praktis mendukung upaya peningkatan prestasi mahasiswa yang dicanangkan di perguruan tinggi. Subjek penelitian ini adalah dua orang mahasiswa yang meraih gelar Mahasiswa Berprestasi lewat kompetisi tahunan Pemilihan Mahasiswa Berprestasi di tingkat universitas. Penelitian ini menggunakan metode kualitatif dengan pendekatan fenomenologis dan metode fenomenologi transendental untuk analisis data wawancara. Penelitian ini berfokus pada penemuan makna dan pemahaman proses regulasi diri Mahasiswa Berprestasi dalam usahanya mencapai prestasi. Diketahui bahwa regulasi diri bagi Mahasiswa Berprestasi adalah dimilikinya sejumlah pikiran, perasaan, dan tindakan yang berkesesuaian, berkesinambungan dan fokus pada tujuan berprestasi. Regulasi diri adalah proses membawa diri menuju pencapaian tujuan menjadi manusia yang utuh; secara akademik (menjadi mahasiswa berprestasi), sosial (menjadi anak yang berbakti dan kakak teladan) maupun eksistensial (menjadi manusia yang bermanfaat).
\end{abstract}

Kata kunci: regulasi diri, mahasiswa berprestasi

\section{PENDAHULUAN}

Keinginan bangsa Indonesia untuk keluar dari keterpurukan dan meraih kejayaan memberikan tanggung jawab besar terhadap dunia pendidikan tinggi untuk bisa mencetak sumberdaya manusia yang berkualitas. Perguruan tinggi bagaikan kawah candradimuka, tempat menggodok mahasiswa agar ia siap berkiprah di masyarakat dan mendukung pembangunan negara sesuai dengan bidang ilmu dan keahlian masing-masing.

Semua pihak, baik pemerintah, pengelola perguruan tinggi, masyarakat, maupun 
keluarga pun ingin agar mahasiswa berprestasi. Menurut Kamus Besar Bahasa Indonesia (Depdikbud, 1997), berprestasi berarti mempunyai prestasi (atau hasil) dalam suatu hal dari yang telah dilakukan atau diusahakan. Seorang mahasiswa dikatakan berprestasi jika ia sukses dalam tugas akademik maupun non akademik. Ia menguasai bidang ilmu yang ditekuninya dan mencapai nilai hasil belajar yang baik. Ia pun aktif dalam kegiatan-kegiatan yang meningkatkan keterampilan, mengembangkan minat dan mengasah bakat dan potensinya.

Mengamati kecenderungan dalam populasi mahasiswa, keberadaan mahasiswa yang berprestasi adalah suatu hal yang fenomenal. Sebagian dari mereka muncul sebagai mahasiswa yang mendapat gelar Mahasiswa Berprestasi dari mengikuti kompetisi tahunan Pemilihan Mahasiswa Berprestasi. Kehidupan dan proses yang mereka jalani hingga mereka berhasil mencapai prestasi tinggi menarik perhatian peneliti. Di tengah kondisi kebanyakan mahasiswa merasa cukup dengan mencapai yang biasa-biasa saja, Mahasiswa Berprestasi tampak tidak demikian.

Salah satu faktor personal yang mempengaruhi prestasi seseorang adalah kemampuan melakukan regulasi diri (Woolfolk, 2010), yakni kemampuan menghasilkan pikiran, perasaan dan tindakan, merencanakan dan mengadaptasikannya secara terus-menerus untuk mencapai tujuan (Zimmerman, 2000).

Regulasi diri merujuk pada dilakukannya kontrol terhadap diri sendiri, terutama untuk menjaga diri tetap berada dalam jalur yang sesuai dengan standar yang dikehendaki (Vohs \& Baumiester, 2004). Regulasi diri merupakan proses penyesuaian yang ber-sifat mengoreksi diri sendiri, yang dibutuhkan untuk menjaga seseorang tetap berada pada jalur menuju tujuan dan penyesuaian tersebut berasal dari dalam diri sendiri (Carver \& Scheier, 2000). Regulasi diri adalah proses seseorang mengaktifkan dan memelihara pikiran, perasaan, dan tin-dakannya untuk mencapai tujuan personal (Zimmerman, 2000); baik tujuan yang bersifat akademik, emosional, sosial (Patrick, 1997; Santrock, 2008; Woolfolk, 2010;), dan spiritual (McCullough \& Willoughby, 2009).

Regulasi diri mencakup area kehidupan yang luas, termasuk lingkungan akademik. Pembelajar yang mampu melakukan regulasi diri cenderung berhasil secara akademik. Mereka mampu belajar secara efektif dengan mengkombinasikan keterampilan belajar akademis (academic learning skill) dan kontrol diri yang membuat proses belajar menjadi lebih mudah sehingga mereka lebih termotivasi. Sebagai pembelajar, mereka memiliki dua hal yang diperlukan dalam berprestasi, yaitu keterampilan dan kemauan (Woolfolk, 2010).

Menurut Zimmerman (2000), proses regulasi diri merupakan suatu siklus yang terdiri dari tiga fase, yaitu (1) fase pemikiran awal (forethought phase); (2) fase tindakan atau kontrol kehendak (performance/volitional control phase); dan (3) fase refleksi diri (self-reflection phase). Dalam setiap fase, terdapat beberapa subproses seperti yang ditunjukkan pada Gambar 1. Subproses tersebut merupakan hal-hal yang dilakukan seseorang ketika meregulasi dirinya pada setiap fasenya. Kemampuan regulasi diri dibentuk melalui proses yang panjang di mana pengasuhan memiliki andil yang besar. Kemampuan regulasi diri sulit dipelajari jika seseorang dibesarkan dalam keluarga atau komunitas yang tidak mengajarkan, meneladankan, dan menghargai regulasi diri (Zimmerman, 2000). Seseorang yang dibesarkan dalam keluarga yang menetapkan standar yang tinggi, menekankan tanggung jawab, dan 
pencapaian akademik diketahui memiliki kemampuan regulasi diri yang tinggi (Santrock, 1999). dipenuhi, maka regulasi diri merupakan suatu cara yang dilakukan mahasiswa untuk menyelaraskan semua kegiatannya sehingga tidak ada salah satu bidang yang terabaikan.

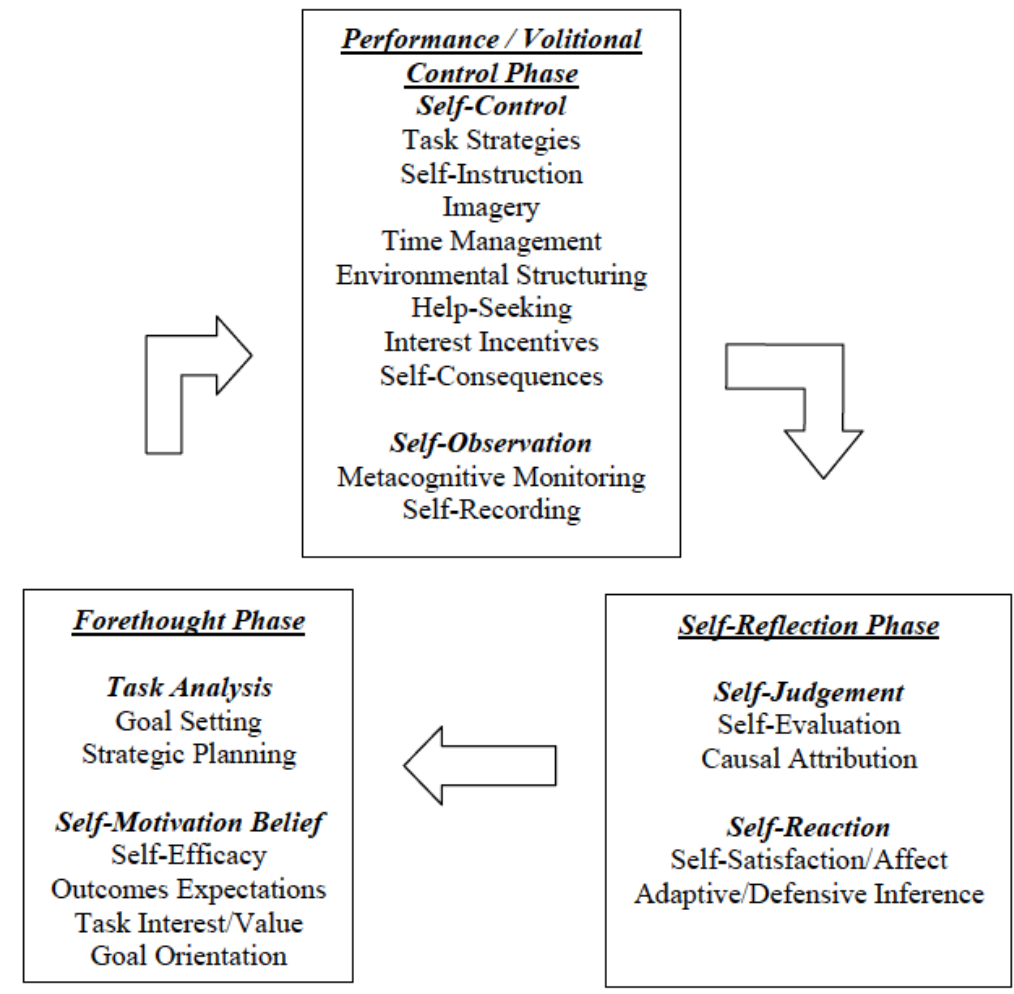

Gambar 1.

Subproses dalam Siklus Proses Regulasi Diri (Zimmerman \& Moylan)

Kebanyakan orang menjadi mahasiswa pada masa remaja akhir (usia 17-18 tahun). Pada usia ini, isu kemandirian, kehidupan yang independen dari orangtua, dan karier mulai memuncak (Newman \& Newman, 2009). Ketika seseorang menjadi mahasiswa, tugas dan tanggung jawabnya tidak hanya seputar diri sendiri dan keluarga, tetapi juga masyarakat. Hal-hal tersebut mempengaruhi bagaimana mahasiswa menentukan tujuan, minat, atau orientasi hidupnya.

Mahasiswa Berprestasi tidak hanya mencapai prestasi di satu bidang saja, tetapi beberapa lainnya, seperti akademik, organisasi, pekerjaan, dan sosial. Dengan banyaknya peran dan tugas yang harus
Untuk berprestasi tinggi, mahasiswa menetapkan tujuan dan target prestasi yang tinggi. Mahasiswa menerapkan strategistrategi untuk memotivasi diri, mengawasi diri, mengelola diri secara ketat, dan mengevaluasi diri untuk menilai sejauh mana ia telah membuat kemajuan.

Regulasi diri dipengaruhi oleh ada tidaknya kesempatan (Boekaerts \& Niemivierta, 2000). Mahasiswa akan meregulasi dirinya jika kondisi lingkungan optimal baginya, tidak terlalu mengatur aspek-aspek dari tugas atau tuntutan dan lingkungan belajar serta memberikan kebebasan untuk bertindak dalam mencapai tujuan (Pintrich, 2000). Ketersediaan sumber belajar juga turut berpengaruh karena berkaitan dengan 
kesempatan yang dimiliki mahasiswa untuk mengembangkan diri dan mempelajari halhal baru lewat sumber-sumber belajar yang tersedia, misalnya buku, jurnal, internet, dan tempat untuk bertanya (Boekaerts \& Niemivierta, 2000).

Regulasi diri memiliki dimensi sosial. Jika seseorang mengabaikan lingkungan sosial atau memandang lingkungan sosial sebagai penghambat, maka regulasi dirinya tidak akan efektif (Zimmerman, 2000). Mahasiswa akan mencari dukungan sosial, seperti afeksi, saran, maupun barang, untuk meningkatkan kemampuan meregulasi diri (Jackson Mackenzie, \& Hobfoll, 2000).

Pertanyaan yang diajukan dalam penelitian ini adalah: Apa makna esensial dari pengalaman regulasi diri yang dilakukan oleh Mahasiswa Berprestasi dalam usahanya untuk berprestasi?

\section{METODE}

Penelitian ini menggunakan metode kualitatif fenomenologis untuk memahami makna esensial dan mengungkapkan dunia pengalaman secara psikologis (Giorgi \& Giorgi, 2009).

Subjek penelitian ini adalah dua orang mahasiswa berprestasi yang diperoleh dengan menggunakan teknik sampling purposif. Kriteria inklusi subjek dalam penelitian ini adalah: 1) tercatat sebagai mahasiswa aktif di perguruan tinggi; 2) mendapat gelar Mahasiswa Berprestasi berdasarkan kompetisi tahunan Pemilihan Mahasiswa Berprestasi di tingkat universitas dan nasional. Subjek I (AH) berusia 20 tahun dan Subjek II (RM) berusia 21 tahun. Keduanya berjenis kelamin perempuan, anak sulung, suku Jawa, beragama Islam, dan sedang menempuh studi di semester 8 .
Data dikumpulkan menggunakan metode wawancara. Analisis data dilakukan dengan metode fenomenologi transendental dengan prosedur yang dirumuskan oleh Moustakas (1994) sebagai berikut: (1) membuat transkripsi hasil wawancara dan memahami keseluruhan pengalaman dengan membaca berulang-ulang; (2) melakukan horisonalisasi untuk menghasilkan unit-unit makna; (3) melakukan pengelompokan (clustering) dan menentukan tema dari unit-unit makna yang dikelompokkan; (4) membuat deskripsi tekstural dan deskripsi struktural individual; (5) mengidentifikasi tema-tema umum dan khusus; (6) menyusun deskripsi gabungan yang mengintegrasikan pengalaman seluruh subjek; serta (7) menyusun esensi.

\section{HASIL DAN PEMBAHASAN}

Peneliti mendapatkan informasi mengenai subjek melalui internet dan jejaring sosial. Pada tahun 2010 terdapat sembilan orang mahasiswa yang menjadi finalis Pemilihan Mahasiswa Berprestasi di tingkat nasional. Peneliti memutuskan mengambil subjek yang terjangkau bagi peneliti yaitu mahasiswa dari dua universitas di Kota Semarang.

Berdasarkan hasil analisis data wawancara (proses horisonalisasi) terhadap kedua subjek, diperoleh 36 konstituen yang tak bervariasi (horison) dan konstituen tersebut dikelompokan ke dalam 12 tema umum. Kedua belas tema yang menyusun proses regulasi diri subjek tersebut, selanjutnya dikelompokan ke dalam tiga kategori, yaitu (1) motif-motif dalam proses regulasi diri; (2) proses regulasi diri dan pencapaian prestasi; dan (3) faktor-faktor pendukung.

Motif-motif dalam proses regulasi diri

Regulasi diri kedua subjek dimulai dari adanya kesadaran dan pemahaman bahwa berprestasi adalah suatu yang baik, penting 
dan karenanya, harus. Walaupun lingkungan (keluarga) memberikan tekanan yang besar untuk berprestasi, prestasi adalah hal yang diinginkan dari dalam diri sendiri.

\section{Memenuhi kewajiban terhadap keluarga}

Ketika meregulasi diri, keharusan berprestasi dirasakan oleh kedua subjek berada di dalam koridor menjalankan tugas "menjadi kakak teladan" dan berbakti kepada orangtua. Dikaitkan dengan kedudukan kedua subjek sebagai anak sulung, kewajiban untuk berprestasi diterima sebagai keharusan yang inheren. Prestasi adalah keniscayaan bagi si sulung, sesuai dengan prinsip keluarga bahwa anak tertua bertugas sebagai model bagi perkembangan anak-anak yang lebih muda. Dalam konsep kedua subjek terpatri bahwa anak tertua haruslah baik, ideal, tidak hanya menyangkut prestasi akademik, tetapi juga baik dalam berbagai macam hal, seperti perilaku, mentalitas, dan kepribadian.

Prestasi diusahakan demi membahagiakan dan berbakti kepada orangtua. Dihubungkan dengan keluarga (orangtua), kegagalan atau tidak berprestasi menjadi hal yang secara moral tidak diperkenankan, memunculkan rasa bersalah dan terasa sangat menyedihkan. Selain karena akan mengecewakan orangtua, risiko dari tidak berprestasi juga dirasakan begitu besar bagi kelangsungan hidup keluarga. Ada kepentingan keluarga yang ingin dijaga dengan cara berprestasi (AH: terkait usaha yang dikerjakan oleh orangtua; RM: masa depan keluarga, terutama hidup saudarasaudara yang lebih muda).

\section{Memenuhi kebutuhan diri akan prestasi}

Regulasi diri dilakukan untuk memenuhi dua hal, yaitu mencapai kepuasan pribadi dan memelihara integritas diri. Motif tersebut bersumber dari kesadaran tentang pentingnya berprestasi. Bagi kedua subjek, baik proses pencapaian prestasi yang penuh kerja keras maupun prestasi yang berhasil diraih, memberikan sesuatu yang positif bagi diri sendiri, berupa kegembiraan, rasa bangga, dan rasa puas yang besar.

Kebiasaan berprestasi pun memberikan keistimewaan tertentu untuk tidak dikenal sebagai "orang yang biasa-biasa saja”. Kedua subjek "tidak pernah tidak berprestasi”; selalu berada di atas rata-rata. Prestasi sebagai bukti kapasitas diri pun membuahkan kepercayaan diri untuk berekspektasi besar dan menetapkan targettarget atau standar pribadi yang tinggi. Karena itu, kondisi tidak berprestasi dalam arti mengalami penurunan atau menjadi yang "biasa-biasa saja” dirasakan sebagai kondisi yang tidak nyaman secara psikologis dan sosial (mengecewakan, memalukan, dan tidak menenangkan).

\section{Mencapai kebermaknaan hidup}

Sebagai sumber kebermaknaan hidup, regulasi diri terkait dengan dua motif yang prinsipil dan mempengaruhi cara kedua subjek menjalani hidupnya, yaitu: (1) mengada (eksis) sebagai manusia yang bermanfaat; (2) membuktikan (kemampuan) diri. Kedua subjek menghayati keinginan menjadi bermanfaat sebagai panggilan hidup (AH: "itu the best passion in my life"; RM: "this is the life I want"). Hidup terasa menyenangkan (memuaskan, membahagiakan), ketika bisa bermanfaat dengan cara berbagi hal-hal baik atau kelebihan yang dimiliki diri dengan orang lain.

"Membuktikan diri" adalah tekad menunjukkan dengan bukti yang nyata bahwa diri bisa mengada (eksis) sebagai manusia yang berdaya, mampu merealisasikan / menjadikan nyata keinginan atau target yang telah ditetapkan dan menjadi manusia dengan kualitas seperti yang diharapkan. Semakin tinggi prestasi yang dicapai, semakin membuktikan kebisaan dan mempertegas keyakinan bahwa "saya ini bisa”. 
Sebagai prinsip, jalan hidup "bermanfaat" merupakan jalan hidup yang prestatif (membawa diri menuju prestasi) dan mendorong diri untuk melakukan regulasi karena satu-satunya cara untuk menjadi baik adalah dengan melakukan hal-hal baik sebaik mungkin. Prinsip tersebut memotivasi, mendorong atau mempercepat gerak subjek, seberapa pun sulit dan enggannya, untuk tetap maju ke depan dan naik ke atas. Ia mempengaruhi berbagai keputusan hidup, berperan sebagai alasan rasional di balik tindakan-tindakan, seperti keputusan memilih dan menjalani aktivitas, pertemanan, proses belajar, bahkan bekerja di usia muda.

\section{Proses regulasi diri dan pencapaian prestasi}

Peneliti membagi pengalaman subjek meregulasi diri ke dalam empat masa, yaitu: (1) masa pramahasiswa; (2) masa mahasiswa awal; (3) masa pertengahan; dan (4) masa mahasiswa akhir. Peneliti mencatat bahwa setiap masa memiliki isuisu yang khas dan sangat mempengaruhi diri subjek. Seiring dengan berjalannya waktu, baik target maupun strategi regulasi diri pun mengalami perubahan yang bersifat adaptif.

\section{Masa pramahasiswa}

Masa pramahasiswa adalah saat sebelum subjek menjadi mahasiswa. Regulasi diri pada saat ini berkaitan dengan persiapan diri untuk menjadi mahasiswa dan menghadapi masa depan/kehidupan orang dewasa. Terdapat dua hal yang sangat menentukan pada masa pramahasiswa, yaitu memiliki orientasi diri yang linear dan komitmen untuk menjadi mahasiswa yang berprestasi.

Berorientasi adalah memiliki suatu hal yang dijadikan pedoman untuk mengarahkan aktualisasi diri. Pada prakteknya, memiliki orientasi adalah tahu apa yang diinginkan dan apa yang harus dilakukan untuk mencapai keinginan tersebut. Adanya orientasi diri yang jelas terlihat ketika subjek memutuskan menjadi mahasiswa. Mereka memilih jurusan demi suatu rencana dalam benak (ada cita-cita yang ingin diwujudkan; ada keberhasilan yang hendak dicapai di masa depan) dan sesuai nature (karakter dan kualitas yang khas) diri mereka sendiri.

Di dalam kelinearan orientasi, ada kemantapan preferensi. Satu hal yang membuat keputusan menjadi teguh adalah karena perasaan suka dilandasi oleh pengetahuan tentang apa yang terbaik bagi diri. Meskipun prosesnya tidak selalu menyenangkan, kedua subjek menyimpulkan tentang pentingnya membuat pilihan yang jujur dan tidak bertentangan dengan kenyataan diri yang menyukai dan mengaspirasikan sesuatu. Kesesuaian adalah kunci ketenangan batin, dan penentu keberhasilan. Dalam pandangan kedua subjek, menjalani hal yang sesuai dengan diri akan memunculkan rasa menerima dan mau bertanggung jawab.

Komitmen berprestasi merupakan janji yang dibuat kedua subjek dan ditujukan pada diri mereka sendiri bahwa mereka akan melakukan yang terbaik dalam menjalani studi mereka. Semangat untuk berprestasi dan meregulasi diri setidaknya didorong oleh dua hal, yaitu: (1) rasa bersyukur kepada Tuhan atas keberhasilan menjadi mahasiswa di jurusan yang diimpikan; dan (2) kesadaran harus bertanggung jawab atas pilihan jalan hidup.

Kedua subjek mengalami proses yang tidak mudah untuk masuk universitas. Perjuangan untuk berada di universitas yang tepat, di jurusan yang diinginkan, tidak selancar yang diharapkan dan melibatkan pengalaman nyaris gagal. Ketika harapan berhasil terwujud, rasa puas dan senang diiringi rasa syukur yang besar kepada Tuhan. 
Keberhasilan yang diatribusikan pada adanya pertolongan Tuhan memunculkan kewajiban untuk menjadi mahasiswa yang berprestasi, seperti yang dikatakan RM: “...pas udah keterima, rasa puasnya dan rasa bersyukurnya itu diikuti dengan janjijanji bahwa aku pasti tidak akan menyianyiakan ini, dan pasti akan melakukan yang terbaik, dan aku pasti juga nggak akan melakukan yang macem-macem..."

\section{Masa mahasiswa awal}

Pada masa ini, kedua subjek menjalani kehidupan sebagai mahasiswa yang masih baru dan menghadapi lingkungan belajar serta pergaulan yang juga baru. Tema yang muncul adalah adaptasi strategis, menyangkut usaha mencari “jalan damai” untuk keluar dari masalah akademik dan sosial yang dialami, dan mengkompromikan antara situasi dan tuntutan lingkungan dengan diri yang berkomitmen untuk berprestasi.

Masa awal menjadi mahasiswa dirasakan sebagai masa yang sulit. Tidak semua hal / orang di sekitar sesuai dengan ekspektasi, berjalan secara ideal dan mendukung usaha mencapai prestasi. Sebagai sebuah strategi, adaptasi merupakan cara subjek mengatasi permasalahan tipikal mahasiswa baru dan membangun hidup yang stabil dengan melakukan berbagai perubahan untuk menemukan metode terbaik untuk belajar dan bergaul.

Kesadaran itu mendorong $\mathrm{AH}$ untuk tidak lagi memandang teman sebagai penghambat, melainkan sumber dukungan yang potensial. Ia ingin menjalin pertemanan yang baik dan memperbaiki hubungan dengan teman-temannya dengan menjadi pribadi yang lebih baik secara sosial dan mencari cara belajar yang tidak mengganggu orang lain. Sedangkan bagi RM, kesadaran itu membuatnya memandang dosen dengan cara yang lebih istimewa sebagai kunci percepatan diri yang dikehen- dakinya. Ia “menyalip” teman-temannya dengan cara membangun jaringan.

Keberhasilan beradaptasi ini menjadi pijakan untuk menjalani kehidupan di masa selanjutnya di mana tugas dan tuntutan menjadi semakin intens. Sejak tahu cara menghadapi lingkungan yang efektif, belajar maupun bersosialisasi, mereka membangun hidup yang lebih pasti dan menenangkan secara psikologis; mencapai prestasi akademik dan mendapatkan temanteman yang menjadi sumber dukungan sosial. Seiring dengan berjalannya waktu, kedua subjek mendapatkan apa yang mereka inginkan lewat proses adaptasi (nilai bagus, teman-teman, dan pekerjaan).

\section{Masa pertengahan mahasiswa}

Masa mahasiswa pertengahan adalah masa di mana subjek mulai menjalani kehidupan yang stabil dan jauh lebih kompleks dalam belajar maupun beraktivitas. Tema yang muncul adalah (1) manajemen belajar; (2) manajemen aktivitas; berkaitan dengan komitmen dalam menjalani kehidupan dengan aktivitas yang kompleks serta strategi yang dijalankan untuk mencapai keberhasilan dalam belajar dan beraktivitas. Manajemen berisi tindakan-tindakan, metode, cara, atau strategi untuk menghadapi tugas-tugas akademik dan menjalani aktivitas organisasi dengan baik untuk mencapai target yang ditetapkan, yaitu keberhasilan.

Pertama, kedua subjek memandang aktivitas belajar dan organisasi sebagai sesuatu yang dapat berjalan bersama-sama, saling melengkapi dan mendukung satu sama lain. Kedua, aktif berorganisasi merupakan keinginan dari dalam diri subjek dan sejak awal disadari konsekuensinya bahwa mereka harus bekerja lebih keras dan menghadapi berbagai kesulitan. Ketiga, mereka bersedia mengalami kesusahan dan bekerja keras demi memastikan kesuksesan atau kelancaran aktivitas belajar dan 
organisasi dengan cara mengorbankan kepentingan / kesenangan pribadi dan lebih ketat dalam mengatur diri dan waktu.

Aktivitas belajar kedua subjek dicirikan oleh adanya empat hal: (1) minat intrinsik dan sikap positif terhadap aktivitas akademik yang dijalani; (2) orientasi pada prestasi belajar dan pemahaman; 3) metode belajar yang strategis; dan 4) kondisi tenang dan stabil dalam berproses. Kunci semangat belajar subjek adalah rasa suka; suka tempat belajar, suka mata kuliah yang dipelajari, dan suka para pengajar mereka.

Kunci keberhasilan akademik adalah belajar dan menjaga pemahaman. Mereka belajar dengan cara yang adaptif terhadap tuntutan aktivitas yang tinggi, nature atau karakter mata kuliah dan bidang studi, serta karakter diri, kekuatan dan kelemahannya, dalam belajar. Strategi yang dilakukan memuat sikap fokus, aktif, dan antisipatif yang mengindikasikan komitmen mereka terhadap prinsip dan kewajiban akademik.

Dalam beraktivitas, manajemen merupakan hal yang disadari kedua subjek harus dilakukan. Pertama, karena aktivitas yang dijalani adalah aktivitas yang disukai, diinginkan dari dalam diri sendiri. Kedua, karena aktivitas tersebut berkaitan dengan kepentingan orang banyak di mana seiring dengan berjalannya waktu dan peningkatan kedudukan, amanat terkait aktivitas menjadi semakin berat.

Kedua subjek senantiasa mengatur aktivitas keseharian mereka. Hari-hari dilalui sesuai dengan rencana yang telah dibuat, di mana mereka secara pasti tahu apa yang ingin dicapai/dilakukan secara detail. Mereka atentif pada kebutuhan dan karakter tugas dan memanfaatkan berbagai sumber daya yang ada untuk mendukung pengaturan diri. Keduanya memegang prinsip untuk berbuat sebaik mungkin dan sesegera mungkin. Mereka menunjukkan kesadaran tinggi atas pentingnya waktu bahwa apa yang akan terjadi di masa depan dipengaruhi oleh apa yang dilakukan saat ini.

Manajemen juga berisi tiga hal penting. Pertama, manajemen tidak hanya tentang persoalan bertindak semaksimal mungkin, tetapi juga "beristirahat" seefektif mungkin. Coping stres pun menjadi bagian yang tidak terpisahkan dalam strategi regulasi diri. Kedua, manajemen juga menyangkut persoalan menjaga diri agar tindakan tetap berada di jalur pencapaian tujuan, bukan jalur yang menyimpang, yaitu dengan cara "ingat" hal-hal yang penting dalam hidup. Ketiga, menjalani aktivitas yang kompleks akan menimbulkan kelelahan, tetapi kondisi sehat memungkinkan subjek kuat menerima beban berat dan menguras tenaga.

\section{Masa akhir mahasiswa}

Masa mahasiswa akhir, yaitu masa "menikmati" keberhasilan sebagai mahasiswa setelah mencapai prestasi yang diharapkan. Inilah masa di mana subjek melihat kembali ke belakang dan mengevaluasi apa yang telah dilakukan. Terdapat tiga reaksi yang dimunculkan kedua subjek terkait prestasi mereka, yaitu (1) bersyukur, (2) ikhlas atas kegagalan dan (3) tekad berprestasi yang baru.

Berkaitan dengan keyakinan bahwa Tuhan Penentu segala sesuatu, Maha Berkehendak dan setiap kehendak-Nya adalah baik, respon pertama dan utama kedua subjek atas prestasi mereka adalah sangat bersyukur. Kebersyukuran ini tidak dapat dipisahkan dengan reaksi kedua, yaitu ikhlas menerima "yang dikehendaki Tuhan" dalam pengejaran prestasi, termasuk kegagalan. Kemampuan menerima hal yang tidak ideal dan tidak memandangnya sebagai kekurangan didukung oleh kemampuan melihat sisi baik dari suatu kejadian dan "melupakan" sisi lain dari peristiwa yang mengecewakan. 
Prestasi akhirnya tidak luput dari evaluasi dan hasil dari evaluasi itulah yang pengaruhnya menjangkau ke masa depan. Kedua subjek pun menyadari sifat sementara dari prestasi yang telah dicapai dan bahwa selalu ada hal-hal lain yang lebih baik dan besar untuk dicapai. Evaluasi memberikan kesempatan untuk menyadari realita secara lebih baik, tentang keadaan dunia yang sebenarnya di mana persaingan adalah hal nyata dengan kompetitor yang sama atau lebih berkompeten. Evaluasi atas prestasi memunculkan dua cara menghadapi masa depan, yaitu: (1) waspada dan bergegas memperbaiki diri (AH); dan (2) semakin percaya diri, berani, dan optimis menghadapi persaingan selanjutnya (RM).

\section{Faktor pendukung pencapaian prestasi}

Faktor-faktor pendukung merupakan halhal yang mendukung subjek mencapai prestasi di perguruan tinggi dan menjadi bagian integral dalam proses regulasi diri.

\section{Faktor individual}

Faktor individual adalah faktor pendukung proses regulasi diri yang bersumber dari dalam diri subjek. Selain memiliki motivasi berprestasi yang besar, kedua subjek masuk perguruan tinggi dengan membawa "modal” kebiasaan, karakter diri, dan sikap positif yang dibutuhkan untuk berprestasi sebagai mahasiswa. Dari penuturan kedua subjek tentang pengalaman masa lalu di keluarga dan sekolah, disimpulkan bahwa mereka adalah individu yang telah tertempa. Lewat pengasuhan di dalam keluarga dan sekolah yang menekankan prestasi dan pengaturan diri, keduanya membangun kebiasaan hidup yang positif bagi pencapaian prestasi di perguruan tinggi, seperti mengutamakan pendidikan, mandiri, sikap hidup penuh tanggung jawab, pekerja keras, dan disiplin.

\section{Faktor sosial}

Faktor sosial memainkan perannya lewat keberadaan lingkungan pergaulan dan interaksi sosial yang konstruktif (mendukung prestasi), pilihan aktivitas yang tepat, dan orang-orang di sekitar subjek yang memberikan dukungan secara langsung maupun tidak langsung. Pencapaian prestasi membutuhkan tempat berkembang yang baik melalui pergaulan dan interaksi sosial positif, yang suportif bagi usaha berprestasi. Bergaul dengan teman, senior, dan dosen yang berprestasi sangat bermanfaat dan dengan sengaja dilakukan, antara lain dengan cara berorganisasi.

Dalam konsep yang dianut kedua subjek, prestasi yang sempurna adalah yang seimbang, antara belajar dan berorganisasi. Karena itu, organisasi menjadi aktivitas yang krusial dan pemilihannya berorientasi pada pencapaian prestasi, pengembangan kemampuan dan pencapaian hidup yang produktif. Organisasi tidak hanya menjadi tempat bertemu senior yang diteladani, tetapi juga teman-teman sebaya yang disegani. Dari melihat dan berinteraksi dengan teman yang aktif, semangat berprestasi dan jiwa kompetitif menjadi terpelihara, bahkan bertambah.

Kedua subjek memiliki orang-orang di sekitar mereka yang menjadi tempat bersandar, tempat bergantung, untuk hal-hal yang tidak dapat mereka hadapi sendirian. Orang-orang ini adalah orang kepercayaan mereka, sosok yang menurut mereka paling mengerti diri mereka, orangtua, dan sahabat terdekat. Dari mereka, subjek menerima banyak dukungan di tengah ketidakmampuan; masukan, bimbingan, dan nasihat di tengah kebingungan; atau kritik, koreksi, dan peringatan yang mencegah mereka melakukan hal-hal yang tidak seharusnya, bahkan bantuan material.

\section{Faktor ketuhanan}

Keberhasilan yang diyakini kedua subjek adalah hasil dari kombinasi antara dukungan lingkungan, usaha diri, dan peran Tuhan. Satu hal yang menurut kedua subjek 
membuat mereka bisa mencapai keberhasilan adalah karena mereka memintanya kepada Tuhan. Keduanya meyakini ada peran “Tangan” Tuhan dalam segala sesuatu, termasuk dalam kesuksesan atau kegagalan seseorang. Keduanya meyakini pentingnya beribadah dan doa, sebagai bagian dari usaha regulasi diri untuk mencapai prestasi.

Secara psikologis, keberagamaan ini memberikan pengaruh tertentu. Kepercayaan pada Tuhan memunculkan keberanian untuk berkeinginan besar dan keyakinan diri, membuahkan kemantapan berusaha dan optimisme. Mengatribusikan hasil pada Tuhan pun memunculkan reaksi yang proporsional ketika berhasil maupun gagal; ketika berhasil, tidak lupa diri dalam rasa senangnya; ketika gagal, tidak berlebihan dalam kesedihannya. Keyakinan bahwa "kehendak Tuhan selalu baik" menjadi penengah antara rasa puas dan tidak puas. Keyakinan ini menjadi rem atau sumber kontrol diri ketika diri berada di atas angin maupun buffer atau penyangga diri ketika berada di posisi jatuh.

\section{Esensi}

Pengalaman regulasi diri bagi Mahasiswa Berprestasi adalah dimilikinya sejumlah pikiran, perasaan, dan tindakan yang selaras, berkesinambungan dan fokus pada pencapaian prestasi. Regulasi diri adalah proses membawa diri menuju pencapaian tujuan menjadi manusia yang utuh secara akademik (menjadi mahasiswa berprestasi), sosial (menjadi anak yang berbakti dan kakak teladan), maupun eksistensial (menjadi manusia yang bermanfaat). Regulasi diri adalah berusaha secara holistik; memaksimalkan kapasitas dan sumber daya diri; menjalin hubungan dengan lingkungan secara harmonis, memanfaatkan sumber daya sosial secara efektif dan menerima dukungan sosial; dan menggantungkan diri pada Tuhan sesuai keyakinan religius yang dimiliki.
Regulasi diri adalah menyadari pentingnya kerja keras dan berprestasi bagi diri dan orang lain, aktif mengenal diri, memiliki tujuan hidup yang jelas dan bermakna, merasa takut gagal dan takut mengecewakan orang-orang yang berharap agar diri berprestasi, dan bekerja keras mengendalikan diri tetap bertahan berada di jalur yang prestatif dengan menetapkan target prestasi yang tinggi, mengatasi hambatan-hambatan internal dan eksternal, menyesuaikan diri dengan lingkungan, mengelola diri, proses belajar, dan aktivitas secara efektif dan ketat, membuka diri untuk menerima tantangan berprestasi lebih tinggi, dan di akhir, mensyukuri proses yang dilalui dan apapun hasil yang dicapai, serta kembali bertekad untuk berprestasi.

Regulasi diri adalah perjuangan untuk mencapai keinginan, tetapi melakukan regulasi diri adalah suatu perjuangan; untuk bertahan dalam kesulitan dan kelelahan karena menghendaki hidup yang kompleks dan prestasi yang ideal; menahan dan menekan gejolak psikologis manusiawi yang mengganggu (rasa tidak suka, malas, ingin bersenang-senang, ingin menyerah, rasa terbebani, lelah, takut kalah, dan berkecil hati), serta terus-menerus memotivasi diri agar bangkit. Regulasi diri mengandung sebuah ironi; dikeluhkan sebagai proses yang berat, tetapi membanggakan dan membahagiakan, karena proses dan hasilnya tidak pernah siasia dalam membuahkan suatu pertambahan. Regulasi diri dilakukan lantaran adanya harapan akan kebaikan, keberhasilan, dan kesuksesan hidup di masa kini dan masa depan, dan keinginan menghindari nasib buruk menjadi orang yang kalah, gagal, dan mendatangkan akibat buruk bagi kehidupan orang lain. Regulasi diri berorientasi pada perkembangan; dinikmati sebagai perjalanan yang tak mengenal kata puas dan final, sepanjang selalu ada target-target baru yang lebih besar dan lebih tinggi untuk dicapai, sepanjang masih ada bagian dari 
diri yang perlu diperbaiki atau ditingkatkan kualitasnya, dan sepanjang belum selesai tugas dan tanggung jawab yang harus dipenuhi.

Secara umum, penelitian ini mendukung penelitian dan teori regulasi diri yang sudah ada bahwa regulasi diri mendukung keberhasilan seseorang dalam mencapai tujuan-tujuannya (Zimmerman, 2000). Dalam penelitian ini, meskipun dilakukan dalam konteks akademik, diketahui bahwa regulasi diri yang dilakukan mahasiswa berprestasi tidak terbatas pada kehidupan akademiknya, tetapi juga melibatkan dan dipengaruhi oleh kehidupan yang lain, baik individual, sosial, maupun spiritual. Pada intinya, regulasi yang dilakukan tidak bersifat parsial, melainkan menyeluruh atas hidup yang tengah dijalani pada saat menjadi mahasiswa.

Peneliti menemukan adanya pengaruh tugas perkembangan terhadap regulasi diri mahasiswa, mendukung konsep yang dikemukakan oleh Heckhausen (1999). Regulasi diri subjek sangat dipengaruhi oleh kecenderungan diri yang menghendaki otonomi dan ingin hidup mandiri sebagai individu yang mulai dewasa. Selanjutnya, kemandirian atau kedewasaan menumbuhkan rasa tanggung jawab dan usaha mencapai tujuan dengan meregulasi diri.

Bagi remaja, regulasi diri dipengaruhi oleh ketertarikannya pada masa depan yang membuatnya merencanakan hidup, cita-cita, pendidikan, dan kariernya (Demetriou, 2000). Hal ini tampak ketika kedua subjek memutuskan secara tegas akan cita-citanya di masa depan, karier dan bidang studi yang hendak ditekuni pun menjadi titik yang menentukan keberhasilan subjek di perguruan tinggi. Keputusan tersebut menjadi titik awal perjalanan regulasi diri subjek selama menjadi mahasiswa karena satu hal yang menentukan keberhasilan subjek adalah keberhasilannya menjadi mahasiswa di jurusan yang mendukung pencapaian cita-citanya dan sesuai dengan kemampuan dirinya.

Peneliti pun menemukan adanya peran "be goal” bagi proses regulasi subjek. "Be goal" mengacu pada tujuan-tujuan yang bersifat high-order berada pada level abstraksi tertinggi, menjadi sumber nilai referensi dan prinsip, dan menspesifikkan kualitas dari tindakan yang dilancarkan untuk mencapai tujuan, terkait bagaimana seharusnya seseorang bertindak dalam mencapai tujuannya (Power dalam Boekaerts \& Niemivirta, 2000).

Keinginan menjadi mahasiswa yang berprestasi tidak menjadi tujuan yang berdiri sendiri, melainkan berhubungan dengan berbagai keinginan berprestasi dalam dimensi kehidupan yang lain. Dihadapkan pada motif-motif yang dimiliki subjek (bertanggung jawab pada keluarga, memenuhi kebutuhan diri dan mencapai hidup yang bermakna), prestasi yang diperjuangkan lewat proses regulasi diri (terlihat dari adanya tindakan konkret atau pergerakan fisik berprestasi), tampak diposisikan atau berfungsi "hanya" sebagai sarana atau jalan untuk mencapai hal yang lebih besar dan lebih penting tersebut atau diistilahkan sebagai "do goal”. Tujuan lower-order/ do goal yang dihubungkan dengan tujuan-tujuan high-order cenderung dihargai lebih tinggi (Carver \& Scheier dalam Boekaerts \& Niemivirta, 2000). Konsep tersebut menjelaskan mengapa tindakan seperti giat belajar, aktif dan berkomitmen dalam berorganisasi, berusaha menjadi teman yang baik, dan mengikuti kompetisi menjadi aktivitas yang berharga dan diusahakan mati-matian oleh kedua subjek dalam proses regulasi dirinya.

Dalam penelitian ini, proses dan interaksi sosial dalam keluarga jelas sangat menentukan, mendukung teori yang menyatakan bahwa hubungan sosial 
memiliki pengaruh yang kuat dan luas terhadap proses regulasi diri seseorang (Vohs \& Finkel dalam Finkel \& Fitzsimons, 2011). Hubungan sosial mempengaruhi subjek terkait tujuan yang hendak dicapai (bertanggung jawab terhadap orangtua), mempengaruhi usaha mencapai tujuan dengan memberikan dukungan sosial dan sumber kekuatan psikologis untuk meregulasi diri, mempengaruhi motivasi dan strategi, serta mempengaruhi kontrol terhadap pencapaian tujuan (misalnya orangtua dijadikan sumber motivasi).

Pencapaian prestasi erat kaitannya dengan persoalan identitas "siapa saya”. Bagi kedua subjek, diri mereka adalah "kakak teladan dan anak yang berprestasi”, “orang yang tidak biasa-biasa saja” sehingga selamanya "saya harus mampu menjadi teladan dan berprestasi”, kapan pun, di mana pun, bagaimana pun juga. Kedua subjek hidup dengan konsep diri yang mengedepankan prestasi; yang berkaitan dengan kebutuhan dan usaha memelihara diri untuk tetap menjadi diri yang ideal.

Penemuan ini mendukung konsep yang dikemukakan oleh Carver dan Scheier (2000) bahwa tujuan yang dimiliki seseorang dalam proses regulasi diri sebagian berkaitan dengan diri orang itu sendiri; "self is partly the person's goal". Sebuah tujuan menjadi penting karena dihubungkan pada konsep diri seseorang. Konsep diri berisi pengetahuan tentang siapa diri seseorang di masa lalu dan di masa kini, serta gambaran diri potensial yang ingin diwujudkan sehingga membimbing pergerakan diri bagi pencapaiannya di masa depan.

Peneliti menemukan bahwa proses regulasi diri untuk berprestasi adalah suatu hal yang unstoppable. Setiap kali mencapai sesuatu, selalu ada hal yang lebih besar yang ingin dicapai, demikian kurang lebihnya, disepakati oleh kedua subjek. Satu hal yang menjadikan prestasi selalu diinginkan adalah karena prestasi memberikan "sesuatu" secara psikologis: perasaan diri mengalami peningkatan, bermakna, bangga, dan senang, di samping berbagai insentif material dan sosial (penghargaan dan pengakuan sosial) lainnya.

Pencapaian prestasi memberikan efek yang menjamin keberlangsungan keinginan untuk berprestasi lewat pengaruh psikologis yang diberikan, berupa kepuasan hidup, seperti yang disebutkan oleh Sagiv, Roccas dan Hazan (2004) bahwa pencapaian tujuan akan memuaskan kebutuhan psikologis dan mengharmoniskan diri.

Beberapa temuan dalam penelitian ini bersangkutan dengan isu kultural yang kini tengah banyak dikaji mempengaruhi perkembangan kemampuan dan proses regulasi diri. Dari perspektif kolektivistik terhadap regulasi diri, perilaku individu merupakan hasil dari adanya harapan komunal (Jackson, Mackenzie, \& Hobfoll, 2000). Seorang mahasiswa didorong untuk berusaha keras memenuhi harapan orangtua dan sosial. Mampu membuat keluarga bangga dan menjaga nama baik keluarga menjadi insentif yang lebih besar daripada kepuasan pribadi. Siswa Asia didorong untuk menghindari kegagalan karena kekhawatiran akan rasa malu. Takut pada kegagalan justru menjadi pendorong untuk mencapai keberhasilan (Chong, 2007).

Motif dan perilaku berprestasi subjek yang berorientasi pada keluarga menunjukkan kesamaan dengan gambaran umum Chong (2007) akan siswa di Asia. Selain itu, rasa takut mengecewakan keluarga dan perasaan malu, bersalah, dan sedih ketika gagal mencapai prestasi yang diinginkan akan mendorong kerja keras dan kontrol diri.

Masyarakat Indonesia pun dikenal sebagai masyarakat yang religius, dilihat dari ideologi negara yang menjunjung tinggi 
prinsip ketuhanan. Keberagamaan (berdoa dan beribadah) pun menjadi hal yang tidak terpisahkan dari regulasi diri subjek. Lingkungan pergaulan yang religius dipandang sebagai salah satu lingkungan yang kondusif bagi proses regulasi diri dan pencapaian prestasi.

\section{KESIMPULAN}

Proses regulasi diri melibatkan beragam aspek dalam kehidupan mahasiswa. Dalam proses regulasi diri terdapat kesesuaian, kesinambungan, dan fokus antara tindakan dengan target yang ingin dicapai. Proses regulasi diri tidak dilakukan subjek secara sendirian, melainkan dalam hubungan interdependensi dengan lingkungan sosial dan dependensi terhadap Tuhan.

Penelitian ini mendukung penemuan sebelumnya yang menyatakan bahwa regulasi diri menentukan keberhasilan seseorang (Zimmerman, 2000) dan menguatkan temuan tentang regulasi diri orang Asia yang kolektivistik (Jackson, Mackenzie, \& Hobfoll, 2000), terlihat dari orientasi regulasi diri yang fokus pada kebaikan hidup bersama, lewat misi menjadi anak yang berbakti dan kakak teladan. Penelitian ini pun mendukung proposisi McCullough \& Willoughby (2009) tentang peran agama terhadap regulasi diri, terlihat dari adanya integrasi praktik-praktik religius dalam proses regulasi diri subjek dan secara unik mengungkapkan tentang pengaruh kebersyukuran terhadap kontinuitas proses regulasi diri.

\section{DAFTAR PUSTAKA}

Boekaerts, M. \& Niemivierta, M. (2000). Self-regulated learning: Finding a balance between learning goals and ego-protective goals. Dalam $\mathrm{M}$.
Boekaerts, P. R. Pintrich, \& M. Zeidner (Eds.), Handbook of self-regulation. San Diego: Academic Press.

Carver, C. S. \& Scheier, M. F. (2000). On the structure of behavioral selfregulation. Dalam M. Boekaerts, P. R. Pintrich, \& M. Zeidner (Eds.), Handbook of self-regulation. San Diego: Academic Press.

Chong, W. H. (2007). The role of personal agency beliefs in academic selfregulation: An Asian perspective. School Psychology International, 28, 63.

Demetriou, A. (2000). Organization and development of self-understanding and self-regulation. M. Boekaerts, P. R. Pintrich, \& M. Zeidner (Eds.), Handbook of self-regulation. San Diego: Academic Press.

Departemen Pendidikan dan Kebudayaan. (1997). Kamus besar Bahasa Indonesia. Jakarta: Balai Pustaka.

Finkel, E. J. \& Fitzsimons, G. M. (2011). The effect of social relationship on self-regulation. Dalam K. D. Vohs \& R. F. Bauminster (Eds.), Handbook of selfregulation: Research, theory, and applications. New York: The Guilford Press.

Giorgi, A. P. \& Giorgi, B. M. (2003). The descriptive phenomenological psychological method. Dalam P. M. Camic, J. E. Rhodes, \& L. Yardley (Eds.), Qualitative research in psychology: Expanding perspective in methodology and design. Washington, DC: American Psychologist Association.

Heckhausen, J. (1999). Developmental regulation in adulthood: Age- 
normative and sociostructural constraints as adaptive challenges. New York: Cambridge University Press.

Jackson, T., Mackenzie, J., \& Hobfoll, S. E. (2000). Communal aspects of selfregulation. Dalam M. Boekaerts, P. R. Pintrich, \& M. Zeidner (Eds.), Handbook of self-regulation. San Diego: Academic Press.

McCullough, M. E. \& Willoughby, B. L. B. (2009). Religion, self-regulation, and self-control: Associations, explanations, and implications. Psychological Bulletin,135(1), 69-93.

Moustakas, C. E. (1994). Phenomenological research methods. Thousand Oaks: SAGE Publication.

Newman, B. M. \& Newman, P. R. (2009). Development through life: A psychosocial approach. Berlmont, CA: Wadsworth Cengage Learning.

Patrick, H. (1997). Social self-regulation: Exploring the relationship between children's social relationship, academic self-regulation, and school performance. Educational Psychologist, 32(4), 209-220.

Pintrich, P. R. (2000). The role of goal orientation in self-regulated learning. Dalam M. Boekaerts, P. R. Pintrich, \& M. Zeidner (Eds.), Handbook of selfregulation. San Diego: Academic Press.
Sagiv, L., Roccas, S. \& Hazan, O. (2004). Value pathways to well-being: Healthy values, valued goal attainment, and environmental congruence. Dalam P. A. Linley \& S. Joseph (Eds.), Positive Psychology in Practice. Hoboken, NJ: John Wiley \& Sons.

Santrock, J. W. (1999). Life-Span Development. Boston: McGraw-Hill.

Santrock, J. W. (2008). Educational Psychology. New York: McGraw-Hill.

Vohs, K. D. \& Baumiester, R. F. (2004). Understanding self-regulation: An introduction. Dalam R. F. Baumiester \& K. D. Vohs. Handbook of SelfRegulation. New York: Guilford Press.

Woolfolk, A. (2010). Educational psychology. Upper Saddle River, NJ: Pearson Education International.

Zimmerman, B. J. (2000). Attaining selfregulation. Dalam M. Boekaerts, P. R. Pintrich, \& M. Zeidner (Eds.), Handbook of self-regulation. San Diego: Academic Press. 